\title{
Genetic polymorphism of fifteen microsatellite loci in Brazilian (blue-egg Caipira) chickens ${ }^{1}$
}

\author{
Graziela Vieira Fonteque ${ }^{2}$, Jaqueline Battilana ${ }^{2}$, Ediane Paludo ${ }^{2}$ \\ and Carlos André da Veiga Lima-Rosa ${ }^{3 *}$
}

\begin{abstract}
Fonteque G.V., Battilana J., Paludo E. \& Lima-Rosa C.A.V. 2014. Genetic polymorphism of fifteen microsatellite loci in Brazilian (blue-egg Caipira) chickens. Pesquisa Veterinária Brasileira 34(1):98-102. Departamento de Medicina Veterinária, Centro de Ciências Agroveterinárias, Universidade do Estado de Santa Catarina, Av. Luiz de Camões 2090, Lages, SC 88520-000, Brazil. E-mail: andrelimarosa@cav.udesc.br

The purpose of this study was to investigate the genetic polymorphism of fifteen microsatellites loci in Brazilian (blue-egg Caipira) chickens. Samples were collected from 100 blue eggs of Caipira chickens from rural properties in the city of Dois Lajeados, RS. After DNA extraction, the fragments related to molecular markers LEI0248, LEI0221, LEI0214, LEI0192, LEI0217, LEI0254, LEI0194, LEI0212, MCW0371, ADL0278, LEI0234, MCW0183, MCW0216, MCW0330 and MCW0081 were obtained by polymerase chain reaction (PCR). The statistical analysis were carried out with the softwares ARLEQUIN 3.5 version and CERVUS 3.0.3 version. The allelic and genotypic frequencies, deviations from Hardy-Weinberg equilibrium, estimates of observed (HO) and expected (HE) heterozygosity and polymorphic information content (PIC) were obtained for each marker locus. A total of 186 alleles from 15 loci were obtained, with sizes ranging of 83 to 490 base pairs. The medium number of alleles was 12.4, the HE was $0.76 \pm 0.14$ and $\mathrm{HO}$ was $0.49 \pm 0.21$ and PIC was 0.706 . The first conclusion is that the microsatellites used are polymorphic and can be used to genetic studies in chickens. The second is that the "Caipira" chicken (blue eggs) population investigated has a great genic variability, which makes than an important source of genetic resources for future animal breeding programs.
\end{abstract}

INDEX TERMS: Genetic polymorphism, poultry, chickens, molecular, genetic variability.

RESUMO.- [Polimorfismo genético de quinze loci de microssatélites em galinhas caipiras brasileiras de ovos azuis.] 0 objetivo deste trabalho foi investigar a variabilidade genética de quinze loci de microssatélites em galinhas caipiras brasileiras de ovos azuis. Foram coletadas amostras de sangue de 100 galinhas caipiras brasileiras de ovos azuis provenientes de propriedades da região rural do município de Dois Lajeados, RS. Após extração do DNA foram

\footnotetext{
${ }^{1}$ Received on June 11, 2013.

Accepted for publication on December 12, 2013.

${ }^{2}$ Departamento de Produção Animal e Alimentos (DPAA), Centro de Ciências Agroveterinárias (CAV), Universidade do Estado de Santa Catarina (UDESC), Av. Luiz de Camões 2090, Bairro Conta Dinheiro, Lages, SC 88520-000, Brazil.

${ }^{3}$ Departamento de Engenharia de Pesca, Centro de Educação Superior da Região Sul (CERES), UDESC, Av. Coronel Fernandes Martins 270, Bairro Progresso, Laguna, SC 88790-000, Brazil. *Corresponding author: andrelimarosa@cav.udesc.br
}

utilizados marcadores para quinze loci de microssatélites: LEI0248, LEI0221, LEI0214, LEI0192, LEI0217, LEI0254, LEI0194, LEI0212, MCW0371, ADL0278, LEI0234, MCW0183, MCW0216, MCW0330 e MCW0081 que foram amplificados por meio da técnica de reação em cadeia da polimerase (PCR). A análise estatística foi conduzida utilizando o programa ARLEQUIN ver 3.5 e CERVUS ver 3.0.3. Foram determinadas às frequências alélicas, genotípicas e estimativas de heterozigosidade esperada (HE) e observada (HO), desvios do Equilíbrio de Hardy-Weinberg e conteúdo de informação polimórfica (PIC) para cada locus de microssatélite. Os resultados demonstraram um total de 186 alelos (somando os alelos dos 15 loci), com os fragmentos variando entre 83 e 490 pares de base, com número médio de alelos de 12,4 , HE de $0,76 \pm 0,14$ e HO de $0,49 \pm 0,21$ e PIC de 0,706 . Conclui-se que os microssatélites utilizados são polimórficos e que podem, portanto, serem utilizados para investigações genéticas em galinhas. A população de gali- 
nhas caipiras de ovos azuis analisada apresenta grande variabilidade gênica, o que as torna uma importante fonte de recursos genéticos, e que poderão, assim, serem utilizadas em futuros programas de melhoramento genético animal.

TERMOS DE INDEXAÇÃO: Polimorfismo genético, aves, molecular, variabilidade genética.

\section{INTRODUCTION}

The introduction of chickens in Brazil is associated to the arrival of the first Europeans navigators in 1500 (Albino et al. 2001). These birds were brought from Orient, Mediterranean and Southern Europe and were left in freedom in the backyards of first properties, in a free way of life with random mating and almost no artificial selection. This kind of creation originated the Brazilian Caipira chickens, a rustic and not commercial specimen of bird (Albino et al. 2001). There are Caipira chickens that ovoposite blue eggs, a heritage of a South American breed chickens, named Araucanas. This race also contributed, by mixture, in the origin of Brazilian Caipira chickens (Lima-Rosa 2004). It is thought that these Caipira birds present considered genetic diversity, and that this feature has facilitated the adaptation of this birds to adverse weather, temperature, food and sanitation conditions (Albino et al. 2001, Lima-Rosa 2004). However, despite this interesting feature, many of these non-commercial populations are at risk of extinction, mainly due to its low productively. To prevent this, it is necessary define strategies for the preservation and conservation these groups that exhibit unique characteristics of adaptability to harsh environments (Barbosa 2006). The evidence of genetic variability in Brazilian (blue-egg Caipira) chickens is one way to demonstrate the importance of conserving these animals for preservation of species diversity. This diversity has been reported by Lima-Rosa et al. (2004) and Lima-Rosa et al. (2005) when they studied a microsatellite locus (LEI0258) and two genes of immune system (B-F genes), in this same population. However, it is necessary to analyze a greater number of loci to obtain a further characterize of this variability. An excellent tool for analyzing DNA polymorphisms are the microsatellite markers or Short Tandem Repeats (STRs). They are moderately repetitive DNA sequences that are present in the genome of vertebrates, insects and plants, and are highly polymorphic (Charlesworth et al. 1994). The objective of this study was investigating 15 microsatellite markers in a population of Brazilian (blue-egg Caipira) chicken.

\section{MATERIALS AND METHODS}

The present study was carried out in the Laboratory Genetic Analysis (DNA-UDESC) do Institute of Molecular Genetics and Animal Breeding (IMEGEM) of University of the State of Santa Catarina (UDESC) located in the city of Lages, SC. The samples are from farms of Dois Lajeados city, RS.

The total DNA extraction of 100 peripheral blood samples was made according to Sambrook et al. (1989). The obtention of DNA fragments related to the loci studied was carried out by the polymerase Chain Reaction (PCR), as described by McConnell et al. (1999). Forward primer for each locus used was label with the fluorescent dyes (FAM). They are LEI0234, LEI0248, LEI0221,
LEI0214, LEI0192, LEI0217, LEI0254, LEI0194, LEI0212 (McConnell et al. 1999), MCW0371 (Fulton et al. 2006), ADL0278, MCW0183, MCW0216, MCW0330 and MCW0081 (FAO 2004). The PCR was performed in a volume of $25 \mathrm{~mL}$ comprising $50 \mathrm{ng}$ of template DNA, $2.5 \mathrm{~mL}$ of $10 \mathrm{X}$ buffer $(100 \mathrm{mM}$ Tris- $\mathrm{HCl}, \mathrm{pH} 8.3$, $500 \mathrm{mM} \mathrm{KCl}), 0.5-2 \mathrm{~mL}(10-40 \mathrm{mM})$ of $\mathrm{MgCl}_{2}, 2 \mathrm{~mL}$ of the dNTP mixture $(0.2 \mathrm{mM}$ of each dNTP), $1 \mathrm{mM}$ of each primer, 0.25 unit of Taq DNA polimerase (Invitrogen) and $\mathrm{H}_{2} \mathrm{O}$ ultra-pure to complete the final volume. The amplification conditions were: 1 min denaturation at $96^{\circ} \mathrm{C}$ followed by 35 cycles of denaturation at $96^{\circ} \mathrm{C}$ for $1 \mathrm{~min}$, annealing at either $51-58^{\circ} \mathrm{C}$ for 30 seconds and extension at $72^{\circ} \mathrm{C}$ for 30 seconds; and one more final extension at $72^{\circ} \mathrm{C}$ for 3 minutes. The eletrophorese of DNA fragments was carried out in the ABI 3130 (Apllied Biosystems) and genotyping was done with Gene Mapper ID Software v3.2 (Apllied Biosystems). The values of allelic and genotypic frequencies, estimates of expected (HE) and $(\mathrm{HO})$ observed heterozygosity, and departure of Hardy-Weinberg equilibrium (EHW) were obtained with ARLEQUIN software version 3.5. The polymorphic information content (PIC) was also calculated to each locus with the software CERVUS 3.0.3 version.

\section{RESULTS AND DISCUSSION}

The genetic diversity of a population can be measured by genotype and allelic frequencies, by the proportion of polymorphic loci and also by observed and expected heterozigosities (Nei 1973). A total of 186 alleles to all loci were found, with their fragments ranging of 83 to 490 base pairs (Table 1). The allele number per locus of microsatellite per chicken population can vary widely, from only one (mono-

Table 1. Polymorphism of 15 microsatellites loci in 100 DNA samples from Brazilian (blue-egg Caipira) chickens

\begin{tabular}{lcccccc}
\hline Locus & $\mathrm{N}_{\mathrm{a}}{ }^{\mathrm{a}}$ & $\mathrm{Ho}^{\mathrm{b}}$ & $\mathrm{He}^{\mathrm{c}}$ & $\mathrm{S}^{\mathrm{d}}(\mathrm{pb})$ & $\mathrm{P} \mathrm{value}^{\mathrm{e}}$ & $\mathrm{PIC}^{\mathrm{f}}$ \\
\hline LEI0248 & 13 & 0.70115 & 0.76447 & $210-258$ & 0.00000 & 0.738 \\
LEI0221 & 21 & 0.81609 & 0.86944 & $168-232$ & 0.00000 & 0.873 \\
LEI0214 & 14 & 0.29885 & 0.80845 & $129-281$ & 0.00000 & 0.732 \\
LEI0192 & 22 & 0.66667 & 0.89104 & $230-378$ & 0.00000 & 0.878 \\
MCW0371 & 17 & 0.26437 & 0.84905 & $198-229$ & 0.00000 & 0.804 \\
LEI0217 & 23 & 0.55172 & 0.83702 & $174-330$ & 0.00000 & 0.914 \\
LEI0254 & 02 & 0.08046 & 0.34981 & $83-87$ & 0.00000 & 0.305 \\
LEI0194 & 08 & 0.17241 & 0.77138 & $125-181$ & 0.00000 & 0.727 \\
LEI0212 & 28 & 0.45977 & 0.87403 & $310-490$ & 0.00000 & 0.845 \\
ADL278 & 05 & 0.56322 & 0.58328 & $102-114$ & 0.00894 & 0.542 \\
LEI0234 & 12 & 0.63218 & 0.82526 & $208-304$ & 0.00000 & 0.792 \\
MCW0183 & 08 & 0.62069 & 0.75809 & $290-318$ & 0.00000 & 0.658 \\
MCW0216 & 05 & 0.35632 & 0.73145 & $124-142$ & 0.00000 & 0.592 \\
MCW0330 & 03 & 0.54023 & 0.73483 & $266-286$ & 0.00000 & 0.581 \\
MCW0081 & 05 & 0.65517 & 0.69796 & $109-130$ & 0.00000 & 0.614 \\
Media & 12.40 & 0.49195 & 0.75637 & & & 0.706 \\
S.d. & 8,21 & 0.21266 & 0.13819 & & & 0.162
\end{tabular}

${ }^{a}$ Number of alleles per locus, ${ }^{b}$ Frequency of observed heterozygosity, ${ }^{\mathrm{c}}$ Frequency of expected heterozygosity, ${ }^{\mathrm{d}}$ Allele sizes in base pairs, ${ }^{\mathrm{e}}$ Locus in disequilibrium $(\mathrm{P}<0.05),{ }^{\mathrm{f}}$ Polymorphic information content.

morphic) to many (polymorphic) (Cheng et al. 1995), if we consider a polymorphic locus that has the most common allele with frequency less than 0,95.

Most studied loci showed high polymorphism in this sample of chickens. This significant variation is evident when comparing these data with those found for the same loci in other works. Clementino (2010) and Clementino et al. (2010) examined 92 samples from four populations of Caipira chickens (called for them of Brazilian chicken 
ecotypes) from northeast region of Brazil with ten loci of microsatellites, and encountered 14-16 alleles to locus LEI0192, 8-12 alleles to LEI0221, 9-13 alleles to LEI0217, and 9-10 alleles to LEI0234, in populations with smaller and larger number of alleles respectively. Nasiri et al. (2007) reported one locus (MCW0216) monomorphic and other (ADL0278) with only three alleles in a population of Iranian native chicken. In another population of native chickens Iranian, Nassiri et al. (2007) found three alleles to locus MCW0081, two alleles to locus ADL027, and only one allele to locus MCW0216. In the present study was found 23 alleles to locus LEI0217, 22 alleles to locus LEI0192, 21 to locus LEI0221, 12 to locus LEI0234, and 5 to loci MCW0081, MCW0216 and ADL0278 (Table 1).

A maximum of 28 alleles was detected for locus LEI0212. Is possible that this level of variation means that this locus is in a region of high mutation rate or positive selection. The locus MCW0371, for example, showed 17 alleles. It is known that this locus is mapped on microchromosome 16, a position very close to the region B-F/B-L (chicken MHC) (Fulton et al. 2006), and that has selection in favor of the perpetuation of mutation. On the other hand, some loci presented low polymorphism, how the loci LEI0254 with two alleles and MCW0330 with three alleles. Based on the same principle discussed above, these loci are in regions of low mutation incidence or are under negative selection. In relation to the average number of alleles per population, all of loci analyzed presented high level of polymorphism.

The medium number of alleles was 12.4 what is remarkably higher than most studies that have reported microsatellite variability in chickens. To breed chickens or commercial lineages (broiler or laying hens), the average number of alleles per locus ranged of 1.3 to 8.1 in studies of Croojimans et al. (1996), Dávila et al. (2009), Emara et al. (2002), Groen et al. (1994), Hillel et al. (2003), Kaiser et al. (2000), Liu et al. (2008), Vanhala et al. (1998) and Zhang et al. (2002).

To non-commercial birds, the values of medium alleles per locus observed were from 3.4 to 9.3 (Hillel et al. 2003, Kaya et al. 2008, Nasiri et al. 2007, Nassiri et al. 2007, Shahbazi et al. 2007, Zhang et al. 2002). These higher values in non-commercial chickens in relation to the commercials are due to a strong pressure of artificial selection that the latter suffer. However, in the population examined here these values were even higher proving the enormous genetic diversity of Brazilian (blue-egg Caipira) chickens.

The expected heterozygosity (HE) is defined by Nei (1973) as the probability that two alleles chosen at random from a population are different. The proportion of heterozygous individuals observed in a population sample is the observed heterozygosity (HO) (Belkhir et al. 1999). These two definitions of average gene diversity can be regarded as measures of genetic variability very informative. The heterozygosity of a marker is defined as the probability of one individual is heterozygous in a locus in question, considering number and frequency of these alleles in population.

According to Ott (1992), a genetic marker is considered polymorphically informative when its heterozygosity is greater than 70\%. Menezes (2005) believes that the obser- ved medium heterozygosity is perceived to be high when the values are superior to 0.7 and reduced to below to 0.5 , while the expected medium heterozygosity with values above to 0.5 indicate high genetic diversity of the markers.

The average of expected and observed heterozygosities were 0.76 and 0.49 (Table 1). To commercial birds (breeds or lines) have been observed medium values of HE between 0.00 (highly inbred lines) and 0.74 and HO from 0.00 to 0.67 (Dávila et al. 2009, Hillel et al. 2003, Tadano et al. 2007, Vanhala et al. 1998, Zhang et al. 2002, Zhou \& Lamont 1999 and Liu et al. 2008). To non-commercial birds the values were from 0.56 to 0,86 (HE), and from 0.38 to 0.63 (HO) (Hillel et al. 2003, Kaya et al. 2008, Nasiri et al. 2007, Nassiri et al. 2007, Shahbazi et al. 2007, Zhang et al. 2002).

The results of this sample are consistent with the values found in non-commercial birds. The estimates of expected heterozygosity (HE) were obtained using the allele frequency data for each locus. The values found to HE per loci ranged of 0.35 to 0.89 , and those of $\mathrm{HO}$ from 0.08 to 0.82 . The largest values of HE and HO were found to loci LEI0192 and LEI0221, and the lowest values found to HE and HO were to locus LEI0254, which presented HE lower than 0.5. To all studied loci, HO values were smaller than HE. The expected and observed heterozygosities, deviations from Hardy-Weiberg equilibrium (P) and polymorphic information content (PIC) are in the Table 1.

The loci LEI0221 and LEI0248 showed high degree of observed heterozygosity, upper than 0.7. Intermediate values between 0.7 and 0.5, appeared in markers LEI0192, LEI0217, ADL278, LEI0234, MCW0183, MCW0081, and MCW0330. On the other hand, the loci LEI0214, MCW0371, LEI0254, LEI0194, LEI0212 and MCW0216 showed low level of observed heterozygosity, less than 0.5 . In total, $60 \%$ of loci had HO superior to 0.5 , and $93.3 \%$ of loci presented values upper than 0.5 to HE. These data suggest a high genetic diversity to the analysed markers. The fifteen loci studied had departure of Hardy-Weinberg Equilibrium (HWE) (Table 1) to analysed population.

Menezes (2005) says that deviations of HWE can be due to several factors as: directed matings, subdivisions within populations, common ancestors, natural or artificial selection, migration or gene flow from an external population, besides the presence of null alleles not detectable experimentally. A common feature in caipira birds is the type of creation system to which they are subjected: extensive breeding of little free populations in the backyards. Are generally not used in the creation any kind of vaccination and antibiotic, and the animals survive at any challenge of health or adverse environmental conditions by own strength.

These small populations usually have individuals with a high degree of relatedness and few male breeders, who are selected for the beauty or physique, increasing rates of consanguinity. The sample of chicken studied exhibit a creation system like that cited above to caipira birds, with free and endogamic populations. These circumstances submit birds to both natural and artificial selection, justifying the EHW deviation found. Several works report the occurrence of these deviations (Granevitze et al. 2007, Dávila et al. 2009, Liu et al. 2008, Nasiri et al. 2007, Nassiri et al. 2007, 
Vij et al. 2006). To select good markers, one can consider the polymorphic information content (PIC), that demonstrates how informative is the marker. Values above $50 \%$ are considered quite informative (Botstein et al. 1980, Costa et al. 2009).

The PIC values encountered to the fifteen microsatellite loci studied varied from 0.305 to 0.914 , and their average to 15 loci was 0.706 (Table 1). In a study of Kaya et al. (2008), the genetic diversity of native chickens from Turquia (Denizli and Gerze) was assessed using 10 microsatellite markers. The PIC values were 0.599 and 0.426 to Denizli and Gerze respectively. Other work with three populations of native chickens from Iran (Dashtiari, Khazak and Zabol) evaluated in 10 microsatellite markers the value of PIC that ranged of 0.500 to 0.810 in these populations (Alipanah et al. 2011). Faced with an overview, the values found to allele medium number and medium heterozygosities in this work, suggests that a high genetic variability exist in Brazilian (blue-egg Caipira) chickens. This elevated genetic diversity shows that is substantial the conservation of these animals as a source of genetic resources. These means could be used in the future in animal breeding programs.

According to Blackburn (2006), due to centuries of domestication and breeding directed (or random), exists today a large number of chicken races in different regions of the planet. However, many of these local breeds of chickens are endangered of extinction, together their valuable genotypes and interesting genetic characteristics.

\section{CONCLUSIONS}

The Brazilian (blue-egg Caipira) chickens demonstrated elevated genetic diversity to loci analyzed, that qualifies as a source of genetic resources and therefore should be preserved.

The microsatellites used in this study were significantly polymorphic, demonstrating high variation in sample (except for the markers LEI0254 and MCW0330). The markers LEI0192, LEI0194; LEI0212; LEI0214, LEI0217, LEI0221, LEI0234, LEI0248, MCW0183 and MCW0371, notably presented high polymorphism making them suitable for analysis of population genetic variability, characterization of breeds and individual profiling, assisting in programs for conservation of genetic resources and animal breeding.

\section{REFERENCES}

Albino L.F.T., Vargas Jr J.G. \& Silva J.H.V. 2001. Criação de Frango e Galinha Caipira: avicultura alternativa. Aprenda Fácil Editora, Viçosa, MG. 124p.

Alipanah M., Torkamanzehi A., Amiry Z. \& Rabani F. 2011. Study of genetic diversity of dashtiari, khazak and zabol chickens using microsatellite markers. Trakia J. Sci. 9:76-81.

Barbosa F.J.V. 2006. Eram caipiras, agora são naturalizadas. Sapiência. Informativo Científico da Fundação de Aparo a Pesquisa do Estado do Piauí (FAPEPI). <http://www.fapepi.pi.gov.br/novafapepi/sapiencia9/ artigos1.php> (April 20, 2009)

Belkhir K. 1999. Genetix: logiciel sous Windows TM pour la génétique des populations. Laboratoire Genóme, Populations, Interations. CNRS UPR 9060, Université Montpellier II, Montpellier, France.

Blackburn H.D. 2006. The National Animal Germplasm Program: challenges and opportunities for poultry genetic resources. Poult. Sci. 85:210215.
Botstein D., White R.L., Skolnick M. \& Davis R.W. 1980. Construction of a genetic linkage map in man using restriction fragment lenght polymorphisms. Am. J. Hum. Genet. 32:314-331.

Costa M.R., Marques J.R.F., Silva C.S. \& Veja Pla J.L. 2009. Distâncias genética em equinos (Equus caballus) por meio de marcadores microssatélites. Revta Biociências 15:18-25.

Cheng H.H., Levin I., Vallegjo R.L., Khatip H., Dodgson J.B., Crittenden L.B. \& Hillel J. 1995. Developing of a genetic map of the chicken with markers of high utility. Poult. Sci. 74:1855-1874.

Clementino C.S. 2010. Caracterização genética de galinhas naturalizadas na região meio-norte do Brasil, com uso de microssatélites. Dissertação de Mestrado em Ciência Animal, Universidade Federal do Piauí, Teresina, PI. 93p.

Clementino C.S., Barbosa F.J.V., Carvalho A.M.F., Costa-Filho R.A.R., Silva G.R., Campelo E.G., Britto F.B. \& Diniz F.M. 2010. Microsatellite DNA loci for population studies in Brazilian chicken ecotypes. Int. J. Poult. Sci. 9:1100-1106.

Crooijmans R.P.M.A., Groen A.B.F., Van Kampen A.J.A., Van Der Beek S., Van Der Poel J.J. \& Groenen M.A.M. 1996. Microsatellite polymorphism in commercial broiler and layer lines estimated using pooled blood samples. Poult. Sci. 75:904-909.

Dávila S.G., Gil M.G., Resino-Talaván P. \& Campo J.L. 2009. Evaluation of diversity between different Spanish chicken breeds, a tester line, and a White Leghorn population based on microsatellite markers. Poult. Sci. 88:2518-2525.

Emara M.G., Kim H., Zhu J., Lapierre R.R., Lakshmanan N. \& Lillehoj H.S. 2002. Genetic diversity at the major histocompatibility complex (B) and microsatellite loci in three commercial broiler pure lines. Poult. Sci. 81:1609-1617.

FAO 2004. Guidelines for Development of National Management of Farm Animal Genetic Resources Plans: Measurement of Domestic Animal Genetic Diversity (MoDAD): Recommnended Microsatellite Markers. Food and Agriculture Organization of the United Nations, Rome. 58p.

Fulton J.E., Juul-Madsen H.R., Ashwell C.M., McCarron A.M., Arthur J.A., O'sullivan N.P. \& Taylor Jr R.L. 2006. Molecular genotype identification of the Gallus gallus major histocompatibility complex. Immunogenetics $58: 407-421$

Gomes P.C. \& Albino L.F. 1998. Criação de Frango e Galinha Caipira. Filmes CPT. Cód.: 050. Série Avicultura, Viçosa, MG.

Granevitze Z., Hillel J., Chen G.H., Cuc N.T.K., Feldman M., Eding H. \& Weigend S. 2007. Genetic diversity within chicken populations from different continents and management histories. Anim. Genet. 38:576-583.

Groen A.F., Crooijmans R.P.M.A., Van Kampen A.J.A., Van der Beek S., Van der Poel J.J. \& Groenen M.A.M. 1994. Microsatellite polymorphism in commercial broiler and layer lines. $5^{\text {th }}$ World Congress on Genetics Applied to Livestock Production, № 21. University of Guelph, Guelph, p.94-97.

Hillel J., Groenen M.A.M., Tixier-Boichard M., Korol A.B., David L., Kirzhner V.M., Burke T., Barre-Dirie A., Crooijmans R.P.M.A., Elo K., Feldman M.W., Freidlin P.J., Mäki-Tanila A., Oortwijn M., Thomson P., Vignal A., Wimmers K. \& Weigend S. 2003. Biodiversity of 52 chicken populations assessed by microsatellite typing of DNA pools. Genet. Select. Evol. 35: 533-557.

Kaiser M.G., Yonash N., Cahaner A. \& Lamont S.J. 2000. Microsatellite polymorphism between and within broiler populations. Poult. Sci. 79:626628.

Kaya M. \& Yildiz M.A. 2008. Genetic diversity among turkish native chickens, denizli and gerze, estimated by microsatellite markers. Biochem. Genet. 46:480-491.

Lima-Rosa C.A.V. 2004. Estudo da variabilidade dos genes B-F (MHC classe I) e de um microssatélite associado a galinhas caipiras brasileiras. Tese de Doutorado em Genética e Biologia Molecular, Universidade Federal do Rio Grande do Sul, Porto Alegre, RS. 96p.

Lima-Rosa C.A.V., Canal C.W., Streck A.F., Freitas L.B., Delgado-Cañedo A., Bonatto S.L. \& Salzano F.M. 2004 B-F DNA sequence variability in Brazilian (blue-egg Caipira) chicken. Anim. Genet. 35:278-384. 
Lima-Rosa C.A.V., Canal C.W., Fallavena P.R.V., Freitas L.B. \& Salzano F.M. 2005. LEI0258 microsatellite variability and its relationship to B-F haplotypes in Brazilian (blue-egg Caipira) chickens. Genet. Mol. Biol. 28:386-389.

Liu G.Q., Jiang X.P., Wang J.Y., Wang Z.Y., Liu G.Y. \& Mao Y.J. 2008. Analysis of genetic diversity of Yangzhou chicken by microsatellite markers. Int. J. Poult. Sci. 7:1237-1241.

McConnell S.K.J., Dawson D.A., Wardle A. \& Burke T. 1999. The isolation and mapping of 19 tetranucleotide microsatellite markers in the chicken. Anim. Genet. 30:183-189.

Menezes M.P.C. 2005. Variabilidade e relações genéticas entre raças caprinas nativas brasileiras. Ibéricas e canárias. Tese de Doutorado Integrado em Zootecnia, Universidade Federal da Paraíba, Universidade Federal Rural de Pernambuco e Universidade Federal do Ceará, Areia, CE. 110 p.

Nasiri B.M.T., Shokri F., Khanian S.E. \& Tavakoli S. 2007. Study on polymorphism of Island native chicken population using microsatellites markers. Int. J. Poult. Sci. 6:835-837.

Nassiri B.M.T., ShorkI F., Hamidi Z. \& Tavakoli S. 2007. The investigation of genetic variation at microsatellite loci in Mazandaran native chickens. Int. J. Poult. Sci. 6:675-678.

Nei M. 1973. Analysis of gene diversity in subdivided populations. Proc. Natl. Acad. Sci. 70:3321-3323.
Ott J. 1992. Strategies for characterizing highly polymorphic markers in human gene mapping. Am. J. Hum. Genet. 51:238-290.

Sambrook J., Fritsch E.F. \& Maniatis T. 1989. Molecular Cloning: a laboratory manual. $2^{\text {nd }}$ ed. Cold Spring Harbor Laboratory Press, Cold Spring Harbor, New York. 236p.

Shahbazi S., Mirhosseini S.Z.M. \& Romanov M.N. 2007. Genetic diversity in five Iranian native chicken populations estimated by microsatellite markers. Biochem. Genet. 45:63-75.

Tadano R., Nishibori M., Nagasaka N. \& Tsudzuki M. 2007. Assessing genetic diversity and population structure for commercial chicken lines based on forty microsatellite analyses. Poult. Sci. 86:2301-2308.

Vanhala T., Tuiskula-Haavisto M., Elo K., Vilkki J., Mä Ki-Tanila A. 1998. Evaluation of genetic variability and genetic distances between eight chicken lines using microsatellite markers. Poult. Sci. 77:783-790.

Vij P.K., Tantia M.S. \& Vijh R.S. 2006. Characterization of Punjab Brown chicken. Anim. Genet. Res. Inform. 39:65-67.

Zhang X., Leung F.C., Chan D.K.O., Yang G. \& Wu C. 2002. Genetic diversity of Chinese native chicken breeds based on protein polymorphism, randomly amplified polymorphic DNA, and microsatellite polymorphism. Poult. Sci. 81:1463-1472.

Zhou H. \& Lamont S.J. 1999. Genetic characterization of biodiversity in highly inbred chicken lines by microsatellite markers. Anim. Genet. 30:256-264. 